\title{
LOCAL RESOURCE-BASED DEVELOPMENT POTENTIAL AS REFLECTED IN WASTE MANAGEMENT/CIRCULARITY TRANSITION: GOVERNANCE BARRIERS IN HUNGARY
}

\begin{abstract}
Waste as a local resource is a development opportunity for resource owners as waste may act as a foundation for bottom-up development at local levels. This paper presents the most important governance challenges that hamper a paradigmatic change in resource efficiency, a transition towards circular economy in the case of Pécs (Hungary). In recent years waste management infrastructure has evolved to provide resource potentials for recycling and reuse, this is a first step towards a (circularity) transition, however, the centralisation of power is hampering local transitions. The article concludes by arguing that in Pécs (Hungary), the transition towards a local resource-based development is impeded by a myriad of legal, institutional and administrative obstacles created by recent efforts towards institutionalisation.
\end{abstract}

Key words: waste management, governance, local resource-based development, sustainability transition, circular economy.

\section{INTRODUCTION}

Since 1992 (United Nations Conference on Environment and Development in Rio de Janeiro), the role of local level sustainability has been evident as "so many of the problems and solutions being addressed by the Agenda 21 have their roots in local activities" (UNCED 1992, Agenda 21, Chapter 28). Hence, the transition towards sustainability needs new approaches, instruments and frameworks in local development activities (Wittmayer and Loorbach, 2016).

\footnotetext{
*Viktor VARJÚ, Cecília MEZEI, KRTK Institute for Regional Studies, 22 Papnövelde Street, 7621, Pécs, Baranya county, Hungary; e-mails: varju@rkk.hu, mezeic@rkk.hu, ORCIDs: https://orcid. org/0000-0003-3954-4518, https://orcid.org/0000-0003-2109-2293

** Csaba VÉR, University of Pécs, Institute of Smart Technology and Engineering, Department of Environmental Engineering, Ifjúság útja 20, 7624 Magyarország Pécs, Hungary; e-mail: ver.csaba@, mik.pte.hu
} 
Waste is often stigmatised as merely something that needs to be disposed of. However, with the drive towards a circular economy (CE), the beneficial reuse of waste as a resource or as an input for other processes has been globally recognised as a paradigmatic change (Mason-Renton and Luginaah, 2018).

As Varjú (2020) in the foreword of this special issue of ESR\&P describes in detail, $\mathrm{CE}$ as a concept has been gaining popularity. Sustainable resource management is a global and borderless phenomenon, and the actors who participate in resource governance are both governmental and non-governmental institutions, as well as agents from the global, national, regional, and local levels (Milligan and O'Keeffe, 2019), each having specific responsibilities and territorial limitations.

Sustainability transitions, beyond traditional planning and development, require broader engagement, empowerment, and breakthrough strategies. As Ghisellini et al. (2016) has indicated, a key aspect of the transition towards $\mathrm{CE}$ comes from the involvement of all actors of a society and from their capacity for creating collaboration and knowledge exchange (Ghisellini et al., 2016). From a former stakeholder survey in the REPAiR ${ }^{1}$ project (Varjú et al., 2019) we know that the perceptions and interpretations of relevant stakeholders regarding sustainable resource management can be considered to be at an advanced level and have a good capacity for collaboration and learning. Although Pécs is a pioneer in waste management in Hungary, today the city is far from being at an advanced level in circular transition. Hence, the research questions here are what circumstances interrupted this promising process in Pécs, and what the main barriers that hamper the use of local resources for local development are.

Based on the investigation in the REPAiR project, this paper presents the possibilities for a transition to a CE in the case of Pécs (Hungary) partly based on the dimensions of the transition to sustainability shaped by Markard et al. (2012), using this as an analytical framework. Regarding waste as a potential resource, this paper elaborates on how power can become a barrier in the transformation of waste to a resource, and hamper local resource-based local development.

The article is organised as follows: the presentation of the analytical framework (second chapter) is followed by a brief introduction of the research method. The fourth chapter is divided into three parts. The first introduces the case study area of Pécs. The second part offers an overview of the sustainability issues of the city, and the third part describes the recent waste treatment situation in Pécs. The fifth chapter discusses the recent governance challenges and the role of power in the waste sector, which is then followed by concluding remarks.

\footnotetext{
${ }^{1}$ REPAiR - REsource Management in Peri-urban AReas: Going Beyond Urban Metabolism, European Union's Horizon 2020 research and innovation programme under grant agreement No 688920. http://h2020repair.eu/
} 


\section{THE DIMENSIONS OF SUSTAINABILITY TRANSITION}

There are numerous on-going discussions on the ideal territorial scale for development policy, and on the scale where local economic development (LED) can be performed. The main approach of LED concepts is that the local level has an important role within development processes through the interactions of local stakeholders and the mobilisation of internal resources (cf. the endogenous development concept Slee, 1994), while there is a potential for the involvement of external resources as well (Mezei, 2019). The local resource-based LED concept endeavours to use all local resources as efficiently as possible. One of the essential features of this local resource-based development approach is not the precondition of development, but its purpose: the intervention's focus on the interests of local actors and local resource owners of a territorial unit, and the interests of all other actors subordinate to it (Mezei and Varjú, 2018).

According to the resource-based approach, all the factors that constitute the set of opportunities and that, at the same time, provide value to developers and users are considered as resources (Mezei, 2018). Adaptive, bottom-up local development has at least three conditions: 1) Mobilisation of locally available community and private resources; 2) Possibility of room for manoeuvre at the local level; and 3) Adaptive use of local development tools (Mezei, 2018).

The efficiency of development policy depends not only on the economy of scale and macro-economic subsidies but also on governance capacities, its social embeddedness, complexity, and its open or closed, hierarchical or horizontal nature. Although local economic development is a multi-layered policy, local governments are the most important actors. The types, amounts and quality of the available resources, social capital, trust, economic development networks, and knowledge are all equally important factors for the success of local economic development (Mezei, 2006; Pálné, 2015).

In the classic approach, waste is both a consequence of human activities and the cause of problems for human health and for the environment (van Ewijk and Stegeman, 2020), however, recently, in the era of transition, it has been a potential local resource, as described in the EU Action Plan for the Circular Economy (EC, 2015), that can be used by adaptive local resource-based developers. In addition, by closing material flow loops, the new approach can generate new business models based on waste as a resource.

Moreno-Pires and Fidélis (2012, p. 609) have argued (citing Bomberg, 2004) that governance for sustainable development can be defined "as the set of institutionalised patterns for interpreting and pursuing sustainable development policies and goals." These new modes of governance give new roles to different governmental levels and actors, and need innovative forms of collaboration and stakeholder involvement. Today, transition management (cf. Loorbach, 2010) and transition governance in sustainability topics such as CE (cf. Heurkens and 
Dąbrowski, 2020) are emerging. These approaches focus on the management and governance peculiarities of cities or regions, which (their space and scale) are also often neglected (Coenen et al., 2012), considering the activities from a strategic, tactical, operational, and reflexive levels (Wittmayer and Loorbach, 2016; Heurkens and Dąbrowski, 2020).

The notion of sustainability transition has been under discussion for 20-30 years and recently, as it being, in many cases, a goal oriented or 'purposive' process (Smith et al., 2005), it includes not only a fundamental transformation in the energy, water, and transportation sectors, but in resource management (towards circular economy) as well (Markard et al., 2012; Truffer and Coenen, 2012; Ghisellini et al., 2016). Apart from the aforementioned Transition management, Strategic niche management, Multi-level perspective, and Technological innovation systems are often cited and discussed as concepts (a detailed overview can be found in Markard et al., 2012).

A sustainability transition as a socio-technical transition involves a broad range of actors and different dimensions: technological, material, organisational, institutional, political, economic, and socio-cultural (Markard et al., 2012). These dimensions are usually discussed in different theoretical approaches to management (mentioned above). As Markard and colleagues (2012) have argued, "there is a pressing need to improve the understanding of the politics and policies of sustainability transitions" (Markard et al., 2012, p. 962). Although politics (including not just the behaviour of a government but also of other actors) is a constant element of a socio-technical transition (Meadowcroft, 2011), it was somehow neglected in the past and has only recently become the focus of discussions (Markard et al., 2012).

This paper focusses on the aforementioned dimension of sustainability transition reflecting on most of the dimensions mentioned by Markad et al. (2012) and on how power and agencies have shaped the sustainability transition processes in Pécs (Hungary) and have finally obstructed the transformation of local resources as a basis for local resource-based development.

\section{METHODS AND MATERIALS}

The methods and materials in this study follow the methodology of the REPAiR project (Obersteg et al., 2017). The literature and document review and the analysis of the legal framework on circularity and resource efficiency in Hungary and Pécs were followed by the identification of relevant stakeholders (including actors in the waste management, NGO, and business sectors). Following the REPAiR project scheme, semi-structured interviews were conducted, during which we asked the interviewees to name additional stakeholders for interview (snowball method). These interviews, a total of ten, were conducted from August to November 2017. 
The interview questions focused on the stakeholders' challenges of having to cope with the transition towards resource efficiency and the practices of resource management. In addition, the interview endeavoured to reveal the knowledge and institutional capacity of different actors with respect to a circular transition and focused on the role of governance and power (at the local and country levels), whether they hamper or facilitate this transition.

In order to gather more information from stakeholders, under the umbrella of Peri-Urban Living Lab (PULL) ${ }^{2}$ (Russo et al., 2017), and as a starting event of the Pécs PULL, a workshop was organised (on $28^{\text {th }}$ November 2017) for relevant local and regional stakeholders (including the city government leadership, experts from the regional green authority, and business actors starting initiatives in circularity). After a few plenary presentations about the recent situation of a sustainability transition in Pécs, the aim of the workshop was to identify the key challenges and objectives for Pécs (including for the local government, the local waste management company, private individuals, business actors) to progress towards a higher level of circularity. (The aim of a follow-up workshop (organised in January 2019) was to rank these challenges and objectives and group them according to three material flows: organic, plastic packaging, and residual waste streams. This workshop has also provided information for this paper.)

Further information was gained during the PULL workshop series organised between January 2019 and January 2020. The main aim of these seven workshops was to co-develop eco-innovative solutions reflecting the challenges identified beforehand. Additionally, beside the main focus, there was an opportunity to consult experts and get more empirical information about the then institutional changes and the role of power in and politicisation of the waste sector.

Based on the above materials, in the following sections a general overview and change over time will be described touching on the technological, material, economic, and socio-cultural dimensions. The fifth section focuses on the challenges of the organisational, institutional, and political dimensions of the circular transition in Pécs, Hungary.

\section{THE CASE STUDY AREA OF PÉCS}

\subsection{Short overview of the geographical and socio-economic situation}

Pécs, the seat of Baranya County in the South Transdanubian Region (Hungary), is situated $30 \mathrm{~km}$ from the Croatian border. This borderline location represented an unfavourable situation in terms of investments due to previous geopolitical

\footnotetext{
${ }^{2}$ See more details in the introductory article of this special issue.
} 
processes in the $20^{\text {th }}$ century (cf. Rácz, 2016; Varjú, 2016). The geographically diverse area of the Baranya county has more than 382,336 inhabitants (in 2018, based on KSH-TeIR database ${ }^{3}$ ).

Coal mining, the basis of Pécs' economy, began in the $18^{\text {th }}$ century with a significant increase in the volume of coal excavation from the beginning of the $20^{\text {th }}$ century. That led to the turning point of the transformation of the city to play a dominant role in the broader region (Faragó, 1997), which "greatly affected the city's traffic, its society, its built environment, general economic development, cultural and intellectual life" (Pirisi et al., 2009, p. 3). In the $20^{\text {th }}$ century, mining continued to have an important role in the economic structure of the city with uranium mining, in addition to coal, also contributing to the socio-economic life of Pécs.

After the decline of this form of heavy industry in the 1980s, and the post1990 industrial restructuring in Hungary (including Pécs), the closure of mines (at the end of the last millennium) had a significant impact on the employment and economy of the city, also leading to the emergence of large, and sometimes 'long-term', brownfield areas (Dannert and Pirisi, 2017). One of their attempt at regenerating them was triggered by the awarding of to the 2010 title of the European Capital of Culture, which provided a possibility to overcome the difficulties for the city of Pécs (Trócsányi, 2011).

The county is considered peripheral and disadvantaged in both social and income aspects (Pénzes, 2014), which is partly manifested in the low economic performance index of GDP/capita: $43 \%$ of the EU28, 63\% of the Hungary average (2015) (Varjú et al., 2018). Pécs, the county's centre, has a disproportionate role in the employment and economic performance of the Baranya county (Varjú et al., 2018). In past decades, the city (with its population of $143,531^{4}$ ) became a university city, and now has around 25,000 students (Gyüre et al., 2013) including 4,500 from abroad, which has an important impact on the society, culture, and economy of the city.

\subsection{Sustainability overview}

The 'green thinking' of certain stakeholders in Pécs is rooted in the 1990s. As a first attempt, Biokom, the local waste management company, introduced separated collection of waste (paper, plastic, and glass), which was a pioneering step in Hungary in 1996. In the early 2000s, the introduction of the Pécs Eco-City, Mecsek-Dráva Ecological Region Programme (ECO-CITY-ECO-REGION) development concept aimed to seek effective solutions to the problems of environmental protection (partly originating from the collapse of the mining and the heavy industries) as a high priority of the county. A major aim of the programme

\footnotetext{
${ }^{3} \mathrm{http} / / / \mathrm{www}$. teir.hu

${ }^{4}$ In 2018, based on KSH TeIR database.
} 
was to mobilise the regional economic and social actors while developing an environmentally conscious market and social behaviour, and integrating the elements of sustainability into the regional and local spatial planning and development processes. To do so, the ECO-CITY-ECO-REGION programme used the ecological footprint as a background concept (Kiss, 2004).

Pécs does not have a (sectorial) plan for waste management, nor for CE (Hungary has no CE plan either). The city's goals for waste management are included in the Integrated City Development Strategy 2014-2020 (ITS, 2014), which contains only one relevant indicator: a higher rate of segregated municipal solid waste. Besides, the city of Pécs has initiated several circular focused green city actions. Among others, renewable energy and energy efficiency are very much highlighted in the strategy, both of which have some history, when the local power plant changed its fuel from coal to biomass in 2004.

Apart from the development of the Sustainable Energy Action Plan (SEAP) in 2014, management and other practical actions for stakeholders in the use of renewable energy and energy efficiency were proposed, a year before the city joined the Covenant of Mayors initiative aiming to reduce $\mathrm{CO}_{2}$ emissions by at least $20 \%$ by 2020 (MANERGY, 2014).

Based on the SEAP, a $10 \mathrm{MWp}$ photovoltaic power plant was built by the city and the local power plant on a brownfield site, a former ash deposit area. Furthermore, on the way towards circularity, a biogas plant on the local wastewater treatment area was also built. The combined cycle-power station provides electricity for the grid, while the thermal energy is used for heating the offices and other buildings of the wastewater treatment centre on site.

\subsection{Waste treatment practice}

By 2016, as a result of a large regional waste development project co-financed by the EU, a new, improved waste management system with new technologies had been established in Pécs and its agglomeration with the dominant contribution from BIOKOM, which played a decisive role in the planning and implementing phases.

Municipal waste subject to mixed collection and separately collected waste are organised as a basic service in Pécs and its agglomeration, maximising the yield of recycled materials while keeping financial sustainability. Hence potential secondary raw materials can be removed from the system at certain processing/ refining points. The mechanical-biological treatment centre (in Kökény, a suburb settlement of Pécs) is responsible for processing mixed waste, which is followed by the biological treatment of its biodegradable fraction. Additionally, in the scope of the above investments, transfer stations were also established in the central settlements of the micro-regions (in the whole project region, not only in the Pécs agglomeration). 
In the analysed area (the Pécs agglomeration of 41 settlements and the city itself), there are two types of segregated collection: collection islands, and doorto-door collection. In the agglomeration, at least one collection point serves each settlement, and, additionally, settlements with populations of 500 to 1,000 have an additional collection point. In major settlements, one additional collection site has been set up per 1,000 inhabitants. Although packaging waste (paper, cardboard, plastics, and glass) are collected, organic waste is excluded for the time being. Door-to-door segregated collection has been introduced in the districts of towns with detached houses and within a $20 \mathrm{~km}$ radius of settlements with more than 15,000 inhabitants. The placing of different capacity collection bins is being continuously monitored. In 2003, door-to-door green waste collection was introduced in the suburban districts of the city. The collected material is composted at the waste treatment site (in Kökény) with a capacity of 9,750 tonnes/year.

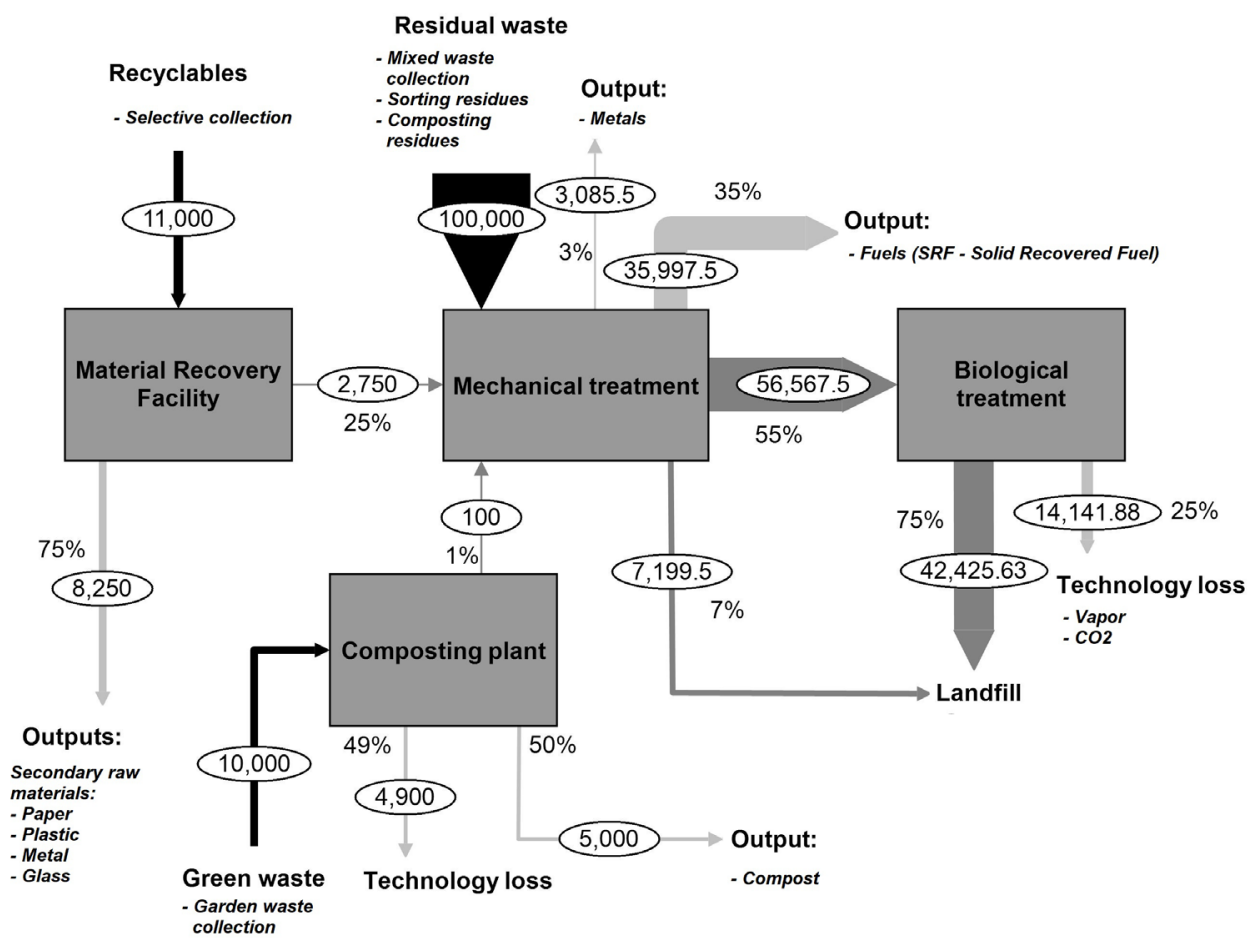

Flows t/year

Fig. 1. Internal waste streams of the Pécs-Kökény site (2017)

Source: own work based on Biokom Nonprofit Ltd data. Designed with STAN2Web open source software 
Fig. 1 shows how the waste is treated at the waste treatment centre in Kökény in order to maximise the yield of recycled materials and to make the most valuable end product. One key flow there is green waste that is transferred into the composting plant.

- $45-50 \%$ of the mass of 9-10 thousand tonnes of incoming green waste is returned as ready-made compost, which is sold for soil improvement purposes. The remainder is released in the form of gases and vapours, except for $1-2 \%$ of foreign matter, which is transferred to the mechanical treatment unit after separation.

- The 10-12 thousand tonnes of dry packaging material collected separately is sorted at a manual sorting plant and segregated, if possible, into pure secondary raw materials by the conveyor belt workers. Paper, plastic and metal raw materials of various qualities are sold in bales, glass is sold in bulk. It is important to note that glass waste is not transferred onto the sorting belt in order to avoid personal injury. Sorting residue (approx. 22-25\%) is taken to the mechanical treatment plant.

- Around 100,000 tonnes of residual waste from mixed collection is delivered to the mechanical treatment unit. The waste transferred from the composting plant and the manual sorting plant that can no longer be recovered is added to this quantity. Solid recovered fuel (SRF) is produced from the light fraction, accounting for $32-38 \%$ of the incoming waste mass.

- The organic fraction from the mechanical treatment plant is first stabilised. This technology is similar to composting, however, due to the collection method (mixed waste) legislation does not allow this material to be composted, only stabilised. The purpose of stabilisation is to decompose organic materials under controlled conditions, preferably aerobic, thus to ensure that $\mathrm{CO}_{2}$ is produced instead of methane, which is a typical by-product of traditional landfills. As a result of biological treatment, one-fourth/one-fifth of the treated volume is removed in the form of gases and vapour and $75-80 \%$ is deposited (Varjú et al., 2018, p. 88).

\section{GOVERNING AND/OR POLITICISING THE WASTE IN HUNGARY}

As a pioneer in the introduction of European policies and principles, BIOKOM has become an internationally known and recognised waste management company, with potential for implementing a paradigmatic change in the field. The potential for reusing waste comes from the waste management infrastructure, however, there are other barriers to overcome, mainly from the side of governance, especially the processes of recent years.

Waste policy is managed to various ministries in Hungary as this policy affects the environmental, public service, and regional development sectors. According to the first post-socialist law on environment in 1995, local governments were made 
responsible for the collection and treatment of locally generated waste (Municipal Solid Waste-MSW), a fact which had led to a fragmented waste management system due to the high number ${ }^{5}$ of local governments in Hungary. Based on the European waste directive, the new Waste Act ${ }^{6}$ was introduced in 2012, which included, among others, waste type definitions and it introduced a waste treatment hierarchy.

As an analysis of the legislation shows, the Hungarian National Waste Management Plan for 2014-20207 was introduced in 2013 (HNWMP 2013). The plan's target was to achieve $50 \%$ reuse of household waste. Segregated waste collection was also a priority. Another aim was to achieve a $28.95 \%$ selection rate of organic waste within MSW. The latter was defined by another important document, the Waste Management Public Service Plan for 2017 (OHKT 2017, p. 42). The Hungarian average in 2016 was very far from that $(13.81 \%)$, however, the percentage in Pécs reached $18.9^{8}$.

From 2013 the contractual freedom of local governments was restricted, as previously they had had the right to sign contracts with waste management public service providers. Since then only one integrated contract has been allowed for the collection and management, and the company has to be majority owned by the local government or a state owned company.

As it is clear from the results of the workshop relating to the ranking of the (circularity) challenges, since 2010 the strong centralisation process within the whole area of governmental and regional development (Nagyházi, 2015), accompanied by a degradation of the independent environmental management system (at all decision-making levels), has also affected waste management. The gaps in environmental governance have been also emphasised by the OECD'.

NHKV Plc. (National Coordination of Waste Management and Asset Management Plc.), a new coordinative organisation (established in 2016), rescaled the entire waste management system. In 2016, the organisation accepted a new regional optimisation plan (HNWMP, 2016) for the provision of the public service of waste management.

The priorities of the new waste management plan 2016 are:

1) Upholding the reduced cost of the waste service (household tariff) 'achieved' by the government;

2) Ensuring a waste service of equal quality in every region;

3) Regional equalisation at the public service provision level;

4) Sustainable financing of the waste management public service (Varjú et al., 2018).

\footnotetext{
${ }^{5}$ There are more than 3,250 settlements in Hungary with self-governmental rights.

${ }^{6}$ The Act CLXXXV of 2012 on wastes.

${ }^{7}$ HNWMP 2013: Hungarian National Waste Management Plan for 2014-2020. http://web.okir.hu/ dokumentum/318/Orszagos_Hulladekgazdalkodasi_Terv_20142020.pdf [accessed on: 01.12.2017]

${ }^{8} \mathrm{https}: / /$ www.teir.hu/

${ }^{9}$ https://www.oecd.org/hungary/hungary-2018-9789264298613-en.htm
} 
The most important effect of the plan has been the (top-down) regionalisation (integration) (cf. Pissourios, 2014) of public waste management. Instead of the former 110 public service providers in 2016, the plan targeted the creation of 20-22 units.

As an analysis of the legislation and the empirical investigations during the PULL project show, since 2017 the selectively collected secondary raw materials from households and the recovered materials from the residual waste on waste treatment sites (including, for example, the new material generated from waste RDF - residue-derived fuels) have been owned by the new organisation instead of the local public service provider (materials collected from the private sector are still subject to market conditions). As a result, local governments with the responsibility for providing the waste service at the local level are unable to manage the local waste (and its potential as a resource) alone. This, in fact, hampers the spread of the circular concept, even at the local level. Hence, local actors have lost their economic interest in moving towards better segregated collection methods, and recovering and reusing secondary raw materials as they do not have the income from sales, while the fixed service price paid by households cannot force regular people to increase segregated collection and allows no room for manoeuvre by the local service provider (e.g. decreasing the price in the case of less residual waste in bins). However, companies using secondary raw materials as resources collected by local service providers are able to purchase them from the NHKV (via public procurement procedure), and are no longer dependent on the limits of the regional waste market.

In 2016, the city generated 48,400 tonnes of municipal solid waste, of which 37,300 tonnes came from households. At the same time, the average per capita waste generation was slightly worse than the national reference value. However, in contrast to national trends, due to a very early introduction of selective waste collection in the city, the proportion of selective waste to total weight has remained above the national average, increasing from 5\% in 2006 to $18.9 \%$ in 2016 . Thanks to the developments, the percentage of waste going to landfills in 2016 was only $51.74 \%{ }^{10}$.

Although the legislative background clearly defined the city's administrative area as the scope of the public waste management service, the city management recognised at an early stage the challenges of scale in the sector. The city management was able to do this with the help of consultants and experts from the by then non-existent mining industry, who were aware of the problem of managing industrial waste. Based on this team of experts, the first public service company owned by the city started to perform waste collection and treatment tasks in Pécs, and then in the surrounding area, based on the principles of economies of scale. This approach has also become a competitive advantage for Pécs. After the temporary privatisation of the public waste management company, at the beginning of the 2000s, BIOKOM Nonprofit Ltd, now re-acquired by the city, has been working to meet EU requirements as soon as possible, on a large-scale basis.

${ }^{10} \mathrm{http}: / /$ www.ksh.hu (Hungarian Statistical Office) 
A higher proportion of household segregated waste collection also contributes to improving the local availability of local resources and secondary raw materials, but at the moment legislation does not encourage households to participate in segregated waste collection. At the same time, key issues include the role of the population, and consumer attitudes and behaviour. Their development will not only provide municipal or corporate actors with opportunities to increase the amount of resources available locally, but it will also provide the public with a cleaner, safer, and livelier environment (as a local resource).

\section{CONCLUSION}

This paper has made an attempt to present the sustainability transition of the city of Pécs in the waste management sector in order to transform resource use towards a more efficient way and to use it locally. Using the (technological, material, organisational, institutional, political, economic, socio-cultural) dimensions of several transitional concepts it has been shown that in the past decades Pécs was a pioneer in waste management transition. However, in past years, taking into account the organisational, institutional, and political dimensions, this transition has been stalled.

The governance of a territory translates to the quality of democracy and public services, therefore, several attempts have been made to make changes in the governance of territories across Europe. Many of these changes were linked to the rescaling of government and its functions, shifting policy responsibilities or the regional development role (Hoffman, 2018) downwards to the local governments (Stead and Pálné Kovács, 2016). In Hungary, since 2010, rescaling has existed in the other direction, i.e. from the local to the central government, shifting the power and the potential of use of local resources to central actors. Due to the centralisation process more and more selectively collected secondary raw materials from households are becoming owned and redistributed by a centralised sectoral body, the NHKV, withdrawing the right of sale from local providers, though allowing the creation of a unified secondary market for these materials. This has resulted in the lack of the opportunity to use these materials locally. This has several negative effects including the increased impact of the transportation of potential resources and the failure to meet local interests in proper 'resource-focused' waste treatment. Hence, although, this reversed change in the competence of local governance does not hamper the transition of the waste sector completely, the potential to use local resources locally, an important aspect of circularity, does not exist.

Acknowledgements. The research presented here has been financed by the H2020 REPAiR project (Grant agreement no. 688920). 


\section{REFERENCES}

BOMBERG, E. (2004), 'Adapting form to function? From economic to sustainable development governance in the European Union', [in:] LAFFERTY, W.M. (ed.) Governance for Sustainable Development: the Challenge of Adapting Form to Function, Edward Elgar: Cheltenham, pp. 61-94.

COENEN, L., BENNEWORTH, P. and TRUFFER, B. (2012), 'Toward a spatial perspective on sustainability transitions', Research Policy, 41 (6), pp. 968-979. https://doi.org/10.1016/j.respol.2012.02.014

DANNERT, É. and PIRISI, G. (2017), ‘Rusty Hungary: New Insights in Brownfield Research', European Spatial Research and Policy, 24 (1), pp. 5-22. http://dx.doi.org/10.1515/esrp-2017-0001

EC, 2015. Closing the loop - An EU action plan for the Circular Economy.

FARAGÓ, L. (ed.) (1997), Pécs-Komló komplex tájrehabilitációs és környezetállapotot javitó programja I-II. Manuscript, MTA RKK DTI: Pécs.

GHISELLINI, P., CIALANI, C. and ULGIATI, S. (2016), 'A review on Circular Economy: the Expected Transition to a balanced interplay of environmental and economic systems', Journal of Cleaner Production, 114, pp. 11-32. https://doi.org/10.1016/j.jclepro.2015.09.007

GYÜRE, J., MAKKAI, B. and TRÓCSÁNYI, A. (2013), 'Az egyetemvárosiasodás kérdései a PTE nyugati kampusza alapján', Területfejlesztés és Innováció, 7 (3), pp. 25-33.

HEURKENS, E. and DĄBROWSKI, M. (2020), 'Circling the square: Governance of the circular economy transition in the Amsterdam Metropolitan Area', European Spatial Research and Policy, 27 (2), pp. 11-31. http://dx.doi.org/10.18778/1231-1952.27.2.02

HOFFMAN, I. (2018), 'Hungarian Counties and Regional development - Changing Roles in a Transforming Environment', Deturope, 10 (3), pp. 162-179.

ITS (2014), Pécs Megyei Jogú Város Integrált Településfejlesztési Stratégiája, 2014-2020. (Pécs Megyei Jogú Város Önkormányzata Közgyülése 261/2014. (09.25.) számú határozatával elfogadva), Eco-cortex Kft. és Msb Zrt. Konzorcium, Pécs.

KISS, T. (2004), Pécs Eco-City Mecsek-Dráva Ecological Region Programme, Executive Summary. Manuscript.

LOORBACH, D. (2010), 'Transition management for sustainable development: a prescriptive, complexity-based governance framework', Governance, 23 (1), pp. 161-183.

MANERGY (2014), http://www.deldunantul.com/sites/default/files/manergy_projektleiras.pdf [accessed on: 02.07.2016]

MARKARD, J., RAVEN, R. and TRUFFER, B. (2012), 'Sustainability transitions: An emerging field of research and its prospects’, Research Policy, 41 (6), pp. 955-967. https://doi.org/10.1016/j. respol.2012.02.013

MASON-RENTON, S.A. and LUGINAAH, I. (2018), 'Conceptualizing waste as a resource: Urban biosolids processing in the rural landscape', The Canadian Geographer / Le Géographe canadien, 62 (2), pp. 266-281. https://doi.org/10.1111/cag.12454

MEADOWCROFT, J. (2011), 'Engaging with the politics of sustainability transitions', Environmental Innovation and Societal Transitions, 1 (1), pp. 70-75.

MEZEI, C. (2016), 'A helyi gazdaságfejlesztés fogalmi meghatározása', Tér és Társadalom, 20 (4), pp. 85-96. https://doi.org/10.17649\%2FTET.20.4.1079

MEZEI, C. (ed.) (2018), Útmutató a helyi erőforrástérkép elkészitéséhez (ajánlás egy erőforrás alapú gazdaságfejlesztést támogató tervezési eszköz alkalmazására) Készült a KÖFOP-2.3.3-VEKOP-16-2016-00001 azonosító jelü "Helyi versenyképesség-fejlesztési kutatási program" címü kiemelt projekt kapcsán. Manuscript. Available at: https://bm-oki.hu/News/ViewFile?fileID $=1130$ [accessed on: 01.04.2020]

MEZEI, C. (2019), Fejlesztési kényszerpályák. Budapest: Dialóg Campus Kiadó. 
MEZEI, C. and VARJÚ, V. (2018), 'Erőforrás-alapú, fenntartható önkormányzati fejlesztések lehetősége/modellezhetősége', [in:] BÁNYAI, O. and BARTA, A. (eds.) A települési környezetvédelem elméleti és gyakorlati megközelitései, Budapest: Gondolat Kiadó, pp. 119-137.

MILLIGAN, B. and O'KEEFFE, M. (2019), 'Global governance of resources and implications for resource efficiency in Europe', Ecological Economics, 155, pp. 46-58.

MORENO-PIRES, S. and FIDÉLIS, T. (2012), 'A proposal to explore the role of sustainability indicators in local governance contexts: The case of Palmela, Portugal', Ecological Indicators, 23, pp. 608-615. https://doi.org/10.1016/j.ecolind.2012.05.003

NAGYHÁZI, Gy. (2015), 'Regional Development Trends and the Regional Development Institutions in the Visegrad Countries - Enabling or Hindering Institutional Environment?', Deturope, 7, pp. 28-44. http://www.deturope.eu/img/upload/content_31421917.pdf

OBERSTEG, A., FRASER, T., ARLATI, A., ACKE, A., BAŃSKI, J., CZAPIEWSKI, K., WÓJCIK, M., MEZEI, C. and VARJÚ, V. (2017), D6.2 Governance and Decision-Making Processes in Follow-up Cases. Resource Management in Peri-urban Areas (REPAiR), Horizon2020, European Commission. http://h2020repair.eu/wp-content/uploads/2019/03/Deliverable-6.2-Governance-and-Decision-Making-Processes-in-Follow-up-Cases.pdf

OHKT (2017), 2003/2017. (XII. 22.) Korm. határozat a 2017. évre szóló Országos Hulladékgazdálkodási Közszolgáltatási Tervröl

PÁLNÉ KOVÁCS, I. (2015), 'Local knowledge based development. What can local governments do for it?', Region: Ekonomika I Sociologija, 4 (88), pp. 261-277.

PÉNZES, J. (2014), Periferikus térségek lehatárolása Magyarországon - módszertani és területi sajátosságok. Available at: http://real.mtak.hu/19472/1/penzes_periferikus_2014.pdf [accessed on: 04.04.2019]

PIRISI, G., STEFÁN, K. and TRÓCSÁNYI, A. (2009), 'A kultúra fôvárosa előtt: a bányászat szerepe Pécs dinamikus funkcionális morfológiájában’, [in:] CSAPÓ, T. and KOCSIS, Zs. (eds.): A közép- és nagyvárosok településföldrajza. Savaria University Press, Szombathely, pp. 257-269.

PISSOURIOS, I.A. (2014), 'Top-Down and Bottom-Up Urban and Regional Planning: Towards a Framework for the Use of Planning Standards', European Spatial Research and Policy, 21 (1), pp. 83-99. https://doi.org/10.2478/esrp-2014-0007

RÁCZ, Sz. (2016), 'Horvátország térszerkezete', Tér és Társadalom, 30 (3), pp. 81-104. https://doi. org/10.17649/TET.30.3.2792

RUSSO, M., AMENTA, L., ATTADEMO, A., CERRETA, M., FORMATO, E; REMØY, H., VAN DER LEER, J. and VARJÚ, V. (2017), D 5.1: PULLsHandbook. Resource Management in Peri-urban Areas (REPAiR), Horizon2020, European Commission. http://h2020repair.eu/ wp-content/uploads/2017/09/Deliverable_5.1_PULLs_Handbook.pdf

SLEE, B. (1994), 'Theoretical Aspects of the Study of Endogenous Development', [in:] VAN DER PLOEG, J.D. and LONG, A. (eds.), Born from within. Practice and Perspectives of Endogenous Rural Development, Van Gorcum, Assen: The Netherlands, pp. 184-194.

SMITH, A., STIRLING, A. and BERKHOUT, F. (2005), 'The governance of sustainable socio-technical transitions', Research Policy, 34, pp. 1491-1510.

STEAD, D. and PÁLNÉ KOVÁCS, I. (2016), 'Shifts in governance and government across Europe', [in:] SCHMITT, P. and VAN WELL, L. (eds.), Territorial governance across Europe. Pathways, Practices, and Prospects, Abingdon: Routledge, pp. 21-35.

TRÓCSÁNYI, A. (2011), 'The spatial implications of urban renewal carried out by the ECC programs in Pécs', Hungarian Geographical Bulletin 60 (3), pp. 261-284. Available at: http://www.mtafki. hu/konyvtar/kiadv/HunGeoBull2011/HunGeoBull_2011_3_261-284.pdf [accessed: 05.03.2019]

TRUFFER, B. and COENEN, L. (2012), 'Environmental Innovation and Sustainability Transitions in Regional Studies', Regional Studies, 46 (1), pp. 1-21. https://doi.org/10.1080/00343404.20 12.646164 
UNCED (1992), Agenda 21. United Nations Conference on Environment and Development: New York. http://sustainabledevelopment.un.org/content/documents/Agenda21.pdf [accessed on: 16.03.2020]

VAN EWIJK, S. and STEGAMANN, J. (2020), 'Recognising waste use potential to achieve a circular economy’, Waste Management, 105, pp. 1-7.

VARJÚ, V. (2016), 'Environmental cohesion across the Hungarian-Croatian border', Bulletin of the Serbian Geographical Society, 96 (1), pp. 81-92. https://doi.org/10.2298/GSGD1601081V

VARJÚ, V. (2020), 'Foreword. Governing Circular Economy - place-specific barriers that hamper to close the loop. Special Issue', European Spatial Research and Policy, 27 (2), pp. 5-10. https:// doi.org/10.18778/1231-1952.27.2.01

VARJÚ, V., MEZEI, C., VÉR, Cs., LOVÁSZ, V., GRÜNHUT, Z., BODOR, Á., SZABÓ, T., JARGALSAIKHAN, K. and AZIZLI, B. (2018), D3.7 Process model Pécs. Resource Management in Peri-urban Areas (REPAiR), Horizon2020, European Commission. http://h2020repair.eu/ wp-content/uploads/2019/03/Deliverable-3.7-Process-model-Pecs.pdf

VARJÚ, V., LOVÁSZ, V., GRÜNHUT, Z., BODOR, Á. and PIRMAJER, A. (2019), D3.8 Report - findings on socio-cultural, socio-economic and company related investigations. Resource Management in Peri-urban Areas (REPAiR), Horizon2020, European Commission. http:// h2020repair.eu/wp-content/uploads/2019/10/Deliverable-3.8-Report-\%E2\%80\%93-findings-on-socio-cultural-socio-economic-and-company-related-investigations.pdf

WITTMAYER, J.M. and LOORBACH, D. (2016), 'Governing Transitions in Cities: Fostering Alternative Ideas, Practices, and Social Relations Through Transition Management', [in:] LOORBACH, D., WITTMAYER, J.M., SHIROYAMA, H., FUJINO, J. and MIZUGUCHI, S. (eds.), Governance of Urban Sustainability transitions, Springer: Japan, pp. 13-32. 